\title{
MINERAL BALANCE DURING BRIEF STARVATION. THE EFFECT ON SERUM ELECTROLYTES AND MINERAL BALANCE OF MAINTAINING THE INTAKE OF CERTAIN MINERAL CONSTITUENTS ${ }^{1}$
}

\author{
BY LEROY E. DUNCAN, JR., RICHARD J. MEYER, AND JOHN EAGER HOWARD \\ WITH THE TECH NICAL ASSISTANCE OF DOROTHY WAGNER AND HARRY EISENBERG
}

\author{
(From the Department of Medicine of the Johns Hopkins University and the \\ Johns Hopkins Hospital)
}

(Received for publication January 13, 1948)

It has long been known that, during starvation, negative nitrogen balance is accompanied by losses of the chief mineral constituents of both the extraand intracellular compartments $(1,2)$. In prolonged fasting (1), in brief fasts followed by graduated increased feeding, and in graduated reduced feeding periods (3), nitrogen, potassium and phosphorus are lost in amounts closely approximating their relative concentration in normal muscle protoplasm, suggesting an even and proportionate expenditure of these intracellular constituents. It was our objective to determine what would occur over a brief period of complete fasting if certain of the usual electrolytes of the diet were furnished orally in the total absence of calorigenic material.

Two obese male patients were studied ; one suffered with diabetes but of such mild intensity that, with the dietary restrictions imposed, he was normoglycemic and aglycosuric. Each patient was observed during two periods of total starvation for four days each, with an intervening period of six days during which he was fed a 1200 calorie diet. In one starvation period water only was allowed, in the other starvation period the same amount of water, plus the sodium, potassium, chloride and phosphorus of the 1200 calorie diet, was administered. The behavior of the weight, electrolyte and nitrogen balances, and changes in certain blood constituents were noted.

\section{Case I}

B. S. (J. H. H. No. 402163), a 53-year-old South American business man, consulted us because of obesity. His family history did not contain relevant disease. He had enjoyed excellent symptomatic health. Varicose veins

1 The work described in this paper was carried out under a contract between the Johns Hopkins University and the Office of Naval Research. of the lower extremities, with slight to moderate afternoon ankle edema, had been present for 10 years. At the age of 40 the patient had weighed 90 kilos. His weight had progressively increased, and at the time he came under our observation, was 128.7 kilos. Four years prior to admission, polyuria and polydipsia had developed, and glycosuria was discovered. He had used insulin for awhile, but his carbohydrate tolerance was such that he was entirely aglycosuric on a diet of 1200 calories.

Examination showed nothing abnormal other than tremendous obesity which was generalized and symmetrically distributed, and varices of the lower extremities, with slight pitting edema. His height was $168 \mathrm{~cm}$. and his weight 128.7 kilos. Blood pressure was 115/70. Blood morphology was normal. Urine, with specific gravity of 1.030 , contained neither sugar nor albumin; and its sediment was clear. Phenolsulphonphthalein excretion was 60 per cent in the first half hour, 85 per cent in two hours. There were no abnormalities in the electrocardiogram. Circulation time was 17 seconds with calcium gluconate; venous pressure was normal, and vital capacity was 3.5 litres.

During the experimental period of 14 days, the patient's activity was standardized. He remained at bed rest with the exception of a 30-minute period each day allowed for shaving and washing. At no time during his stay did the patient have glycosuria, and his highest fasting blood sugar was $124 \mathrm{mgm}$. per cent. Observations were divided into four periods as follows:

Foreperiod. For four days the patient was given a diet calculated to yield 1200 calories, divided into thirds, with 100 grams of carbohydrate, 80 grams of protein, 53 grams of fat. Balance data were not obtained during this period, and the diet was not analyzed. Water was allowed ad libitum. His weight fell from 128.7 kilos to 125.2 kilos. The slight edema disappeared.

Period I. This period lasted four days. During it the patient received no food but was given a mixture of $\mathrm{Ca}_{3}\left(\mathrm{PO}_{4}\right)_{2}, \mathrm{KCl}, \mathrm{NaCl}$, and $\mathrm{NaHCO}_{3}$ in 800 cc. water, taken in divided doses at 8 a.m., 12 noon, 4 p.m. and 8 p.m. By analysis this mixture contained 109 meq. $\mathrm{Na}$; 60 meq. $\mathrm{K}$; 122 meq. $\mathrm{Cl} ; 3400 \mathrm{mgm}$. $\mathrm{Ca}$, and $1460 \mathrm{mgm}$. P. Total water intake was maintained at 3000 cc. per day.

2 The salt mixture was designed to approximate the amount of sodium, potassium, chloride and phosphorus 
TABLE I

Analytic data

\begin{tabular}{|c|c|c|c|c|c|c|c|c|c|c|c|c|c|c|c|c|c|}
\hline \multirow[b]{2}{*}{ Per. } & \multirow[b]{2}{*}{ Date } & \multirow[b]{2}{*}{ Wt. } & \multirow[b]{2}{*}{ Cal. } & \multicolumn{6}{|c|}{ Intake } & \multirow[b]{2}{*}{$\begin{array}{l}\text { Urine } \\
\text { Vol. }\end{array}$} & \multicolumn{7}{|c|}{ Urine } \\
\hline & & & & $\mathbf{N}$ & $\mathrm{Na}$ & $\mathbf{K}$ & $\mathrm{Cl}$ & $\mathrm{Ca}$ & $P$ & & $\mathbf{N}$ & $\mathrm{Na}$ & $\mathrm{K}$ & $\mathrm{Cl}$ & $\mathrm{Ca}$ & $\mathbf{P}$ & $\begin{array}{c}\mathrm{Ti}- \\
\text { trable } \\
\text { acidity }\end{array}$ \\
\hline I & 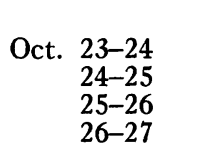 & $\begin{array}{l}\text { kilos } \\
125.2 \\
125.0 \\
124.0 \\
122.7\end{array}$ & $\begin{array}{l}0 \\
0 \\
0 \\
0\end{array}$ & $\begin{array}{c}g m . \\
0 \\
0 \\
0 \\
0\end{array}$ & $\begin{array}{l}\text { meq. } \\
109 \\
109 \\
109 \\
109\end{array}$ & $\begin{array}{l}\text { meq. } \\
60 \\
60 \\
60 \\
60\end{array}$ & $\begin{array}{l}\text { meq. } \\
122 \\
122 \\
122 \\
122\end{array}$ & $\begin{array}{l}m g m . \\
3400 \\
3400 \\
3400 \\
3400\end{array}$ & $\begin{array}{l}m g m . \\
1460 \\
1460 \\
1460 \\
1460\end{array}$ & $\begin{array}{c}c c . \\
1440 \\
2060 \\
2680 \\
2710\end{array}$ & \begin{tabular}{r|}
$g m$. \\
9.2 \\
12.6 \\
10.9 \\
9.5
\end{tabular} & $\begin{array}{l}\text { meq. } \\
123 \\
153 \\
155 \\
177\end{array}$ & $\begin{array}{l}\text { meq. } \\
72 \\
94 \\
97 \\
95\end{array}$ & $\begin{array}{l}\text { meq. } \\
117 \\
180 \\
168 \\
144\end{array}$ & $\begin{array}{l}m g m . \\
152 \\
319 \\
394 \\
380\end{array}$ & $\begin{array}{r}m g m . \\
822 \\
1135 \\
1270 \\
1290\end{array}$ & $\begin{array}{l}37.2 \\
49.8 \\
70.1 \\
75.5\end{array}$ \\
\hline II & $\begin{array}{ll} & 27-28 \\
& 28-29 \\
& 29-30 \\
\text { Oct. } & 30-31 \\
\text { Oct. } & 31-N o v .1 \\
\text { Nov. } 1-2\end{array}$ & $\begin{array}{l}121.2 \\
121.6 \\
122.1 \\
122.2 \\
122.5 \\
122.8\end{array}$ & $\begin{array}{l}1200 \\
1200 \\
1200 \\
1200 \\
1200 \\
1200\end{array}$ & $\begin{array}{l}13.5 \\
13.5 \\
13.5 \\
13.5 \\
13.5 \\
13.5\end{array}$ & $\begin{array}{l}118 \\
118 \\
118 \\
118 \\
118 \\
118\end{array}$ & $\begin{array}{l}74 \\
74 \\
74 \\
74 \\
74 \\
74\end{array}$ & $\begin{array}{l}90 \\
90 \\
90 \\
90 \\
90 \\
90\end{array}$ & $\begin{array}{l}1148 \\
1148 \\
1148 \\
1148 \\
1148 \\
1148\end{array}$ & $\begin{array}{l}1562 \\
1562 \\
1562 \\
1562 \\
1562 \\
1562\end{array}$ & $\begin{array}{r}1740 \\
1260 \\
1160 \\
990 \\
900 \\
1360\end{array}$ & $\begin{array}{r}14.9 \\
11.1 \\
8.3 \\
9.5 \\
9.1 \\
10.6\end{array}$ & $\begin{array}{l}42 \\
14 \\
12 \\
26 \\
30 \\
96\end{array}$ & $\begin{array}{l}94 \\
48 \\
39 \\
37 \\
38 \\
35\end{array}$ & $\begin{array}{l}64 \\
51 \\
36 \\
44 \\
38 \\
62\end{array}$ & $\begin{array}{l}308 \\
174 \\
155 \\
193 \\
210 \\
412\end{array}$ & $\begin{array}{r}1640 \\
840 \\
615 \\
770 \\
656 \\
837\end{array}$ & $\begin{array}{r}113.0 \\
39.6 \\
26.6 \\
35.8 \\
31.2 \\
25.0\end{array}$ \\
\hline III & $\begin{array}{l}2-3 \\
3-4 \\
4-5 \\
5-6\end{array}$ & $\begin{array}{l}122.5 \\
122.1 \\
121.1 \\
120.4\end{array}$ & $\begin{array}{l}0 \\
0 \\
0 \\
0\end{array}$ & $\begin{array}{l}0 \\
0 \\
0 \\
0\end{array}$ & $\begin{array}{l}0 \\
0 \\
0 \\
0\end{array}$ & $\begin{array}{l}0 \\
0 \\
0 \\
0\end{array}$ & $\begin{array}{l}\mathbf{0} \\
\mathbf{0} \\
\mathbf{0} \\
\mathbf{0}\end{array}$ & $\begin{array}{l}0 \\
0 \\
0 \\
0\end{array}$ & $\begin{array}{l}0 \\
0 \\
0 \\
0\end{array}$ & $\begin{array}{l}1900 \\
2380 \\
2645 \\
3000\end{array}$ & $\begin{array}{r}8.0 \\
8.2 \\
10.9 \\
9.8\end{array}$ & $\begin{array}{l}52 \\
54 \\
73 \\
88\end{array}$ & $\begin{array}{l}22 \\
24 \\
40 \\
51\end{array}$ & $\begin{array}{l}44 \\
48 \\
47 \\
33\end{array}$ & $\begin{array}{l}108 \\
135 \\
220 \\
202\end{array}$ & $\begin{array}{r}566 \\
761 \\
1115 \\
1050\end{array}$ & $\begin{array}{l}20.2 \\
30.4 \\
50.8 \\
58.1\end{array}$ \\
\hline & 6 & 119.2 & & & & & & & & & & & & & & & \\
\hline
\end{tabular}

Patient B. S.

Period I. Fasting with salt mixture.

Period II. 1200 calorie diet.

Period III. Fasting with water only.

Period II. During this period, of six days' duration, the patient was given a diet calculated to yield 1200 calories ( C 100, P 80, F 53), which contained by analysis 13.5 gm. N, 118 meq. Na, 74 meq. K, 90 meq. Cl, 1148 $\mathrm{mgm}$. $\mathrm{Ca}$ and $1562 \mathrm{mgm}$. P. Ingested water was maintained at $3000 \mathrm{cc}$. per day (in addition to the preformed water of the diet which amounted to $1495 \mathrm{gm}$.).

Period III. During this period, of four days' duration, the patient received $3000 \mathrm{cc}$. water daily. No food or minerals were given.

\section{RESULTS}

The analytic data and the daily weight of the patient are recorded in Table I. Balances during the last three periods are depicted in Table II and Figure 1. In the foreperiod there was a nitrogen deficit of approximately $3 \mathrm{gm}$. During the first period of starvation, there was a negative nitrogen balance of $45 \mathrm{gm}$.; and, despite the administration of the mineral salts, there was a negative balance of $\mathrm{Na}$, amounting to 220 meq., of $\mathrm{K}, 150$ meq. and of $\mathrm{Cl}, 139$ meq.

During the subsequent six-day period with a

estimated to be present in the 1200 calorie diet. Analysis of the diet was not, of course, known until later. The patient ingested considerably more calcium per day on the salt mixture than on the diet. diet of 1200 calories, there was a positive balance of all these constituents, that for nitrogen amounting to 16 gm., Na 482 meq., K 141 meq. and $\mathrm{Cl} 239$ meq.

In the second fasting period of four days, in which only water was allowed, there was a negative nitrogen balance of $39 \mathrm{gm}$., of $\mathrm{Na}, 275$ meq., of $\mathrm{K}, 165 \mathrm{meq}$. and of $\mathrm{Cl}, 176$ meq. During the first depletion period (salt administration), weight loss was 4 kilos, in the second depletion period (water only) weight loss amounted to 3.3 kilos. During both depletion periods, the patient was hungry, but otherwise complained of no symptoms. He was unable to ascertain that the drinking of the salt mixture, though somewhat disagreeable to take, influenced in any way his general well-being, either for better or worse, as compared with the starvation period without the salts. There were two stools in the period of salt administration, somewhat more liquid than usual for him; whereas stool was obtained only by tap water enema at the end of the starvation period when no salts were ingested. Fecal content of $\mathrm{Na}, \mathrm{Cl}$ and $\mathrm{K}$ indicated that these substances were absorbed. However, the fecal $\mathrm{Na}$ was higher in the starvation period with salt administration than we have 


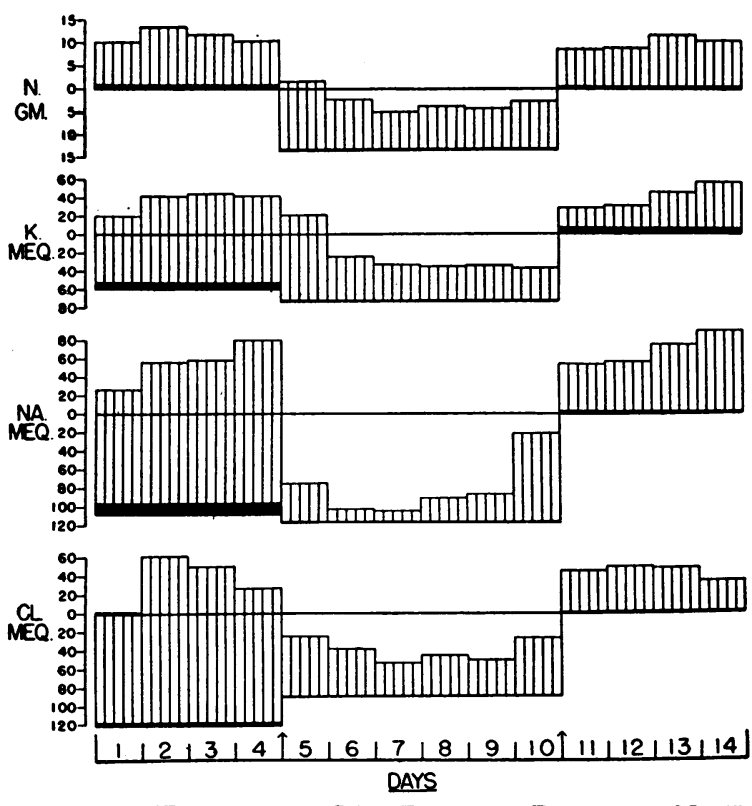

Fig. 1. (Patient B. S.) Balance Data for $\mathrm{N}, \mathrm{K}$, Na and Cl for the Three Periods of Metabolic Study Are Depicted

The lowest line signifies intake, the difference between upper line and lowest line signifies the outgo. Thus if the uppermost line is above the zero line, this signifies that the overall balance of the substance was negative; if below the zero line, the patient was in positive balance. Heavy black represents the content of the constituent contained in the stool.

Days 1 through 4, the patient was starved but given the salt mixture; days 5 through 10 , the patient was fed a 1200 calorie diet; days 11 through 14, the patient was starved and given water only. seen in other than diarrheal states. The content of potassium in the stool differed little in the two starvation periods.

\section{Case II}

J. M. (J. H. H. No. 427946), 28, single, draftsman, sought advice because of obesity. His past history yielded only an attack of inflammatory rheumatism at age 18. He had been overweight as long as he could remember; in the preceding 10 years there had been a gain from 240 to $305 \mathrm{lbs}$. Physical examination was not remarkable except for extreme obesity, which was general in its distribution. Height was $177.5 \mathrm{~cm}$., weight 137.7 kilos. Examinations of the urine, stool and blood morphology were normal. Basal metabolic rate: plus 2. An electrocardiogram was normal. $\mathrm{X}$-rays of the skull were normal save for a small osteoma on the frontal sinus septum. The blood pressure was 120/80 and was uninfluenced by the dietary procedures carried out. Psychiatric consultation confirmed the opinion of the medical staff that the obesity was related to insecurity with resulting phagomania.

The regimens followed on this patient were in general the same as those of Case I, except that in the first period of fasting he was given water only; during the second period water and the salts were given. The salt mixture given to this patient was supposed to be the same as that given to $\mathrm{B}$. S. but on analysis contained much less calcium. ${ }^{3}$

${ }^{3}$ The relatively smaller amount of calcium in the salt mixture given to this patient was not intended. It occurred because, in making up the mixture, dibasic calcium phosphate was inadvertently substituted for the tribasic salt.

TABLE II

Balance data

\begin{tabular}{|c|c|c|c|c|c|c|c|c|c|c|c|c|c|c|c|c|c|c|c|c|c|}
\hline \multirow{2}{*}{ Per. } & \multirow{2}{*}{ Date } & \multicolumn{6}{|c|}{ Stool } & \multicolumn{4}{|c|}{ Balance } & \multicolumn{7}{|c|}{ Serum } & \multirow{2}{*}{ Sugar } & \multirow{2}{*}{$\begin{array}{l}\text { Uric } \\
\text { acid }\end{array}$} & \multirow{2}{*}{ Htct. } \\
\hline & & $\mathbf{N}$ & $\mathrm{Na}$ & $\mathbf{K}$ & $\mathrm{Cl}$ & $\mathrm{Ca}$ & $\mathbf{P}$ & $\mathbf{N}$ & $\mathrm{Na}$ & $\mathbf{K}$ & $\mathrm{Cl}$ & $\mathrm{Na}$ & $\mathbf{K}$ & $\mathrm{Cl}$ & $\left|\mathrm{HCO}_{2}\right|$ & $\mathrm{Ca}$ & $\mathbf{P}$ & NPN & & & \\
\hline I & 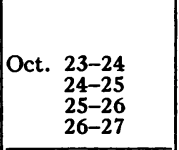 & $\begin{array}{c}g m . \\
.8 \\
.8 \\
.8 \\
.8\end{array}$ & $\begin{array}{l}\text { meq. } \\
12 \\
12 \\
12 \\
12\end{array}$ & $\begin{array}{l}\text { meq. } \\
8 \\
8 \\
8 \\
8\end{array}$ & $\begin{array}{c}\text { meq. } \\
4 \\
4 \\
4 \\
4\end{array}$ & $\begin{array}{c}m g m . \\
156 \\
156 \\
156 \\
156\end{array}$ & \begin{tabular}{|c|}
$m g m$. \\
164 \\
164 \\
164 \\
164
\end{tabular} & $\begin{array}{c}\text { gm. } \\
-10.0 \\
-13.4 \\
-11.7 \\
-10.3\end{array}$ & $\begin{array}{l}\text { meq. } \\
-26 \\
-56 \\
-58 \\
-80\end{array}$ & $\begin{array}{l}\text { meq. } \\
-20 \\
-42 \\
-45 \\
-43\end{array}$ & $\begin{array}{l}\text { meq. } \\
-1 \\
-62 \\
-50 \\
-26\end{array}$ & $\begin{array}{c}\text { meq./ } \\
l . \\
141\end{array}$ & $\begin{array}{c}\text { meq. } \\
l . \\
3.9\end{array}$ & $\begin{array}{c}\text { meq. } \\
l . \\
106\end{array}$ & $\begin{array}{c}\text { meq. } \\
l . \\
27.6\end{array}$ & $\begin{array}{c}\text { mgm. } \\
\% \\
10.0\end{array}$ & $\begin{array}{c}\text { mgm } \\
\% \\
4.5 \\
\end{array}$ & $\begin{array}{c}m g m \\
\% \\
32\end{array}$ & $\begin{array}{c}\text { mgm. } \\
\% \\
114\end{array}$ & $\begin{array}{c}\text { mgm. } \\
\% \\
5.3\end{array}$ & $\begin{array}{l}\% \\
51\end{array}$ \\
\hline II & 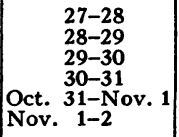 & $\begin{array}{l}.2 \\
.2 \\
.2 \\
.2 \\
.2 \\
.2\end{array}$ & $\begin{array}{l}1 \\
1 \\
1 \\
1 \\
1 \\
1 \\
1\end{array}$ & $\begin{array}{l}2 \\
2 \\
2 \\
2 \\
2 \\
2\end{array}$ & $\begin{array}{l}1 \\
1 \\
1 \\
1 \\
1 \\
1 \\
1\end{array}$ & $\begin{array}{l}247 \\
247 \\
247 \\
247 \\
247 \\
247\end{array}$ & $\begin{array}{l}174 \\
174 \\
174 \\
174 \\
174 \\
174\end{array}$ & $\begin{array}{r}-1.6 \\
2.2 \\
5.0 \\
3.8 \\
4.2 \\
2.7\end{array}$ & $\begin{array}{r}75 \\
103 \\
105 \\
91 \\
87 \\
21\end{array}$ & $\begin{array}{r}-22 \\
24 \\
33 \\
35 \\
34 \\
37\end{array}$ & $\begin{array}{l}25 \\
88 \\
53 \\
45 \\
51 \\
27\end{array}$ & 143 & 4.5 & 104 & 22.8 & 12.2 & 5.4 & 34 & 68 & & 51 \\
\hline III & $\begin{array}{l}2-3 \\
3-4 \\
4-5 \\
5-6\end{array}$ & $\begin{array}{l}.5 \\
.5 \\
.5 \\
.5\end{array}$ & $\begin{array}{l}2 \\
2 \\
2 \\
2\end{array}$ & $\begin{array}{l}7 \\
7 \\
7 \\
7\end{array}$ & $\begin{array}{l}1 \\
1 \\
1 \\
1\end{array}$ & $\begin{array}{l}591 \\
591 \\
591 \\
591\end{array}$ & $\begin{array}{l}376 \\
376 \\
376 \\
376\end{array}$ & $\begin{array}{l}-8.5 \\
=8.7 \\
-11.4 \\
-10.3\end{array}$ & $\begin{array}{l}-54 \\
-56 \\
-75 \\
-90\end{array}$ & $\begin{array}{l}-29 \\
-31 \\
-47 \\
-58\end{array}$ & $\begin{array}{l}-45 \\
-49 \\
-48 \\
-34\end{array}$ & 140 & 4.1 & 109 & 27.6 & 11.1 & 3.4 & 29 & 124 & 5.1 & 48 \\
\hline & 6 & & & & & & & & & & & 137 & 4.3 & 105 & 21.6 & 9.8 & 3.7 & 32 & 66 & 11.1 & 48 \\
\hline
\end{tabular}

Patient B. S.

Period I. Fasting with salt mixture.

Period II. 1200 calorie diet.

Period III. Fasting with water only. 


\section{RESULTS}

The analytical data and daily weight are recorded in Table III. Balance data are given in Table IV and graphically recorded on Figure 2. During the four-day foreperiod, with a diet of 1200 calories, there was a nitrogen deficit of approximately $14 \mathrm{gm}$. In Period I, when only water was allowed for four days, nitrogen loss amounted to $60.6 \mathrm{gm}$., potassium 250 meq., sodium 205.0 meq. and chloride 212 meq. Acetonuria (Rothera test) was found to be 4 plus at the end of this period.

During Period II, six days when 1200 calories daily were given, there was a further nitrogen loss of 2.4 gm.; but potassium, sodium and chloride were retained in amounts of 142, 420 and 258 meq., respectively. Traces of acetone continued to be found in the urine during this entire period.

In Period III, when the patient was fasted and salts were administered with the water, there occurred a negative balance of all constituents; nitrogen 35.5 gm., K 21.0 meq., Na 176.0 meq., .and Cl 118.0 meq. During both periods of starvation the only symptoms complained of by the patient were hunger, weakness and brief morning headache, none of which were more than mildly an-
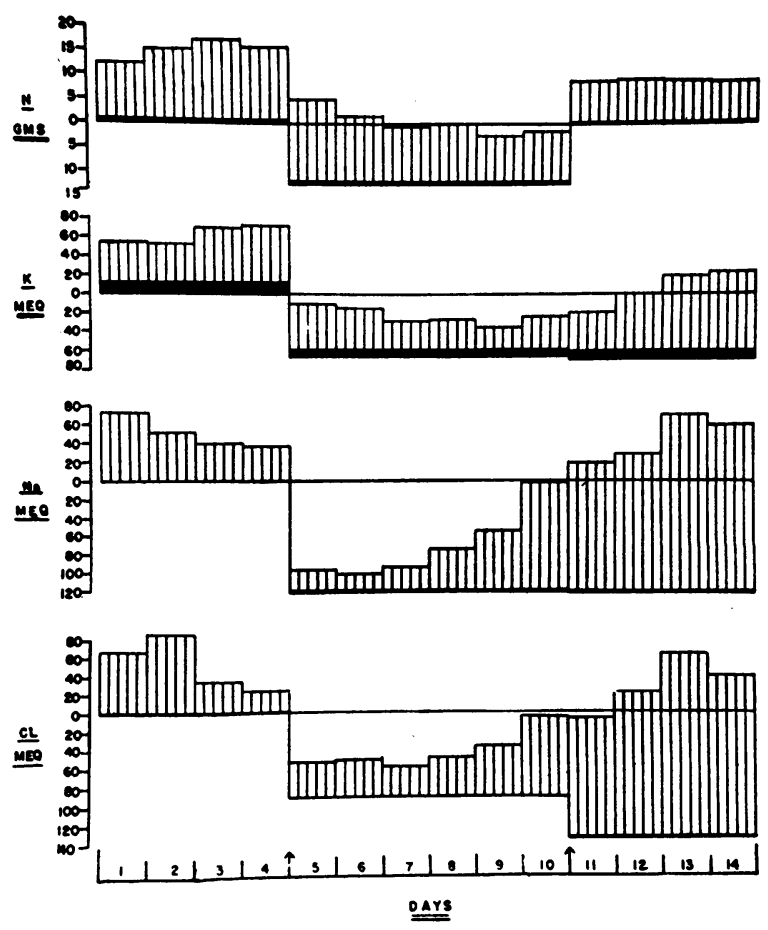

Fig. 2. (Patient J. M.) Balance Data Are Charted AS IN FIGURE 1

Days 1 through 4 , the patient was starved and given water only; days 5 through 10 , the patient was fed a 1200 calorie diet; days 11 through 14, the patient was starved and given the salt mixture.

TABLE III

Analytic data

\begin{tabular}{|c|c|c|c|c|c|c|c|c|c|c|c|c|c|c|c|c|}
\hline \multirow{2}{*}{ Per. } & \multirow{2}{*}{ Date } & \multirow{2}{*}{ Wt. } & \multirow{2}{*}{ Cal. } & \multicolumn{6}{|c|}{ Intake } & \multirow{2}{*}{$\begin{array}{c}\text { Urine } \\
\text { vol. }\end{array}$} & \multicolumn{6}{|c|}{ Urine } \\
\hline & & & & $\mathbf{N}$ & $\mathrm{Na}$ & $\mathbf{K}$ & $\mathrm{Cl}$ & $\mathrm{Ca}$ & $\mathbf{P}$ & & $\mathbf{N}$ & $\mathrm{Na}$ & $\mathbf{K}$ & $\mathrm{Cl}$ & $\mathrm{Ca}$ & $\mathbf{P}$ \\
\hline I & $\begin{array}{r}\text { July } 14-15 \\
15-16 \\
16-17 \\
17-18\end{array}$ & $\begin{array}{c}\text { kilos } \\
132.5 \\
130.9 \\
130.5 \\
129.5\end{array}$ & $\begin{array}{l}0 \\
0 \\
0 \\
0\end{array}$ & $\begin{array}{c}g m . \\
0 \\
0 \\
0 \\
0\end{array}$ & $\begin{array}{c}\text { meq. } \\
0 \\
0 \\
0 \\
0\end{array}$ & $\begin{array}{c}\text { meq. } \\
0 \\
0 \\
0 \\
0\end{array}$ & $\begin{array}{c}\text { meq. } \\
0 \\
0 \\
0 \\
0\end{array}$ & $\begin{array}{c}m g m . \\
0 \\
0 \\
0 \\
0\end{array}$ & $\begin{array}{c}m g m . \\
0 \\
0 \\
0 \\
0\end{array}$ & $\begin{array}{c}c c . \\
680 \\
1180 \\
2180 \\
2020\end{array}$ & $\begin{array}{l}g m . \\
11.3 \\
14.4 \\
16.5 \\
14.8\end{array}$ & $\begin{array}{r}\text { meq. } \\
73 \\
52 \\
39 \\
37\end{array}$ & $\begin{array}{c}\text { meq. } \\
44 \\
42 \\
59 \\
61\end{array}$ & $\begin{array}{r}\text { meq. } \\
67 \\
84 \\
34 \\
23\end{array}$ & $\begin{array}{r}m g m . \\
98 \\
136 \\
220 \\
272\end{array}$ & $\begin{array}{r}m g m . \\
418 \\
688 \\
1230 \\
1180\end{array}$ \\
\hline II & $\begin{array}{l}18-19 \\
19-20 \\
20-21 \\
21-22 \\
22-23 \\
23-24\end{array}$ & $\begin{array}{l}128.2 \\
128.0 \\
127.7 \\
128.6 \\
129.3 \\
129.4\end{array}$ & $\begin{array}{l}1200 \\
1200 \\
1200 \\
1200 \\
1200 \\
1200\end{array}$ & $\begin{array}{l}12.64 \\
12.64 \\
12.64 \\
12.64 \\
12.64 \\
12.64\end{array}$ & $\begin{array}{l}119 \\
119 \\
119 \\
119 \\
119 \\
119\end{array}$ & $\begin{array}{l}67 \\
67 \\
67 \\
67 \\
67 \\
67\end{array}$ & $\begin{array}{l}91 \\
91 \\
91 \\
91 \\
91 \\
91\end{array}$ & $\begin{array}{l}1128 \\
1128 \\
1128 \\
1128 \\
1128 \\
1128\end{array}$ & $\begin{array}{l}1586 \\
1586 \\
1586 \\
1586 \\
1586 \\
1586\end{array}$ & $\begin{array}{l}2020 \\
1680 \\
1840 \\
1960 \\
1620 \\
1880\end{array}$ & $\begin{array}{r}17.2 \\
13.8 \\
11.6 \\
12.2 \\
9.8 \\
10.6\end{array}$ & $\begin{array}{r}22 \\
19 \\
25 \\
40 \\
64 \\
118\end{array}$ & $\begin{array}{l}48 \\
45 \\
31 \\
32 \\
25 \\
37\end{array}$ & $\begin{array}{l}37 \\
38 \\
31 \\
42 \\
54 \\
86\end{array}$ & $\begin{array}{l}232 \\
218 \\
137 \\
183 \\
183 \\
162\end{array}$ & $\begin{array}{r}1120 \\
895 \\
806 \\
760 \\
578 \\
860\end{array}$ \\
\hline III & $\begin{array}{l}24-25 \\
25-26 \\
26-27 \\
27-28\end{array}$ & $\begin{array}{l}129.2 \\
128.9 \\
127.9 \\
127.0\end{array}$ & $\begin{array}{l}0 \\
0 \\
0 \\
0\end{array}$ & $\begin{array}{l}0 \\
0 \\
0 \\
0\end{array}$ & $\begin{array}{l}121 \\
121 \\
121 \\
121\end{array}$ & $\begin{array}{l}70 \\
70 \\
70 \\
70\end{array}$ & $\begin{array}{l}135 \\
135 \\
135 \\
135\end{array}$ & $\begin{array}{l}2300 \\
2300 \\
2300 \\
2300\end{array}$ & $\begin{array}{l}1630 \\
1630 \\
1630 \\
1630\end{array}$ & $\begin{array}{r}880 \\
1840 \\
2260 \\
1800\end{array}$ & $\begin{array}{l}8.2 \\
8.7 \\
8.5 \\
8.5\end{array}$ & $\begin{array}{l}137 \\
148 \\
189 \\
178\end{array}$ & $\begin{array}{l}43 \\
63 \\
81 \\
86\end{array}$ & $\begin{array}{l}127 \\
156 \\
197 \\
174\end{array}$ & $\begin{array}{l}106 \\
131 \\
137 \\
294\end{array}$ & $\begin{array}{l}543 \\
737 \\
904 \\
960\end{array}$ \\
\hline & 28 & 126.0 & & & & & & & & & & & & & & \\
\hline
\end{tabular}

Patient J. M.

Period I. Fasting with water only.

Period II. 1200 calorie diet.

Period III. Fasting with salt mixture. 
TABLE IV

Balance dato

\begin{tabular}{|c|c|c|c|c|c|c|c|c|c|c|c|c|c|c|c|c|c|c|c|c|c|c|}
\hline \multirow{2}{*}{ Per. } & \multirow{2}{*}{ Date } & \multicolumn{6}{|c|}{ Stool } & \multicolumn{4}{|c|}{ Balance } & \multicolumn{7}{|c|}{ Serum } & \multirow{2}{*}{$\begin{array}{l}\text { Uric } \\
\text { acid }\end{array}$} & \multirow{2}{*}{ Htct. } & \multirow{2}{*}{ T.P. } & \multirow{2}{*}{ A/G } \\
\hline & & $\mathrm{N}$ & $\mathrm{Na}$ & $\mathbf{K}$ & $\mathrm{Cl}$ & $\mathrm{Ca}$ & $\mathbf{P}$ & $\mathbf{N}$ & $\mathrm{Na}$ & $\mathbf{K}$ & $\mathrm{Cl}$ & $\mathrm{Na}$ & $\mathbf{K}$ & $\mathrm{Cl}$ & $\mathrm{HCO}_{3}$ & $\mathbf{C a}$ & $\mathbf{P}$ & NPN & & & & \\
\hline I & 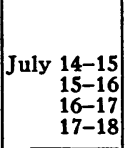 & $\begin{array}{r}g m . \\
.9 \\
.9 \\
.9 \\
.9\end{array}$ & $\begin{array}{r}\text { meq. } \\
.5 \\
.5 \\
.5 \\
.5\end{array}$ & $\begin{array}{l}\text { meq. } \\
11 \\
11 \\
11 \\
11\end{array}$ & $\begin{array}{c}\text { meq. } \\
.6 \\
.6 \\
.6 \\
.6\end{array}$ & $\begin{array}{c}m g m . \\
178 \\
178 \\
178 \\
178\end{array}$ & $\begin{array}{l}m g m . \\
126 \\
126 \\
126 \\
126\end{array}$ & $\begin{array}{c}\mathrm{gm} . \\
-12.2 \\
-15.3 \\
-17.4 \\
-15.7\end{array}$ & $\begin{array}{l}\text { meq. } \\
-74 \\
-53 \\
-40 \\
-38\end{array}$ & $\begin{array}{l}\text { meq. } \\
-55 \\
-53 \\
-70 \\
-72\end{array}$ & $\begin{array}{l}\text { meq. } \\
-68 \\
-85 \\
-35 \\
-24\end{array}$ & $\begin{array}{c}\text { meq.l } \\
l . \\
140\end{array}$ & $\begin{array}{c}\text { meq. } \\
l . \\
3.7\end{array}$ & $\begin{array}{c}\text { meq.I } \\
l . \\
104.4\end{array}$ & $\begin{array}{c}\text { meq.l } \\
l . \\
27.9\end{array}$ & $\begin{array}{c}\text { mgm. } \\
\% \\
10.7\end{array}$ & $\begin{array}{c}m g m . \\
\% \\
3.7\end{array}$ & $\begin{array}{c}m g m \\
\% \\
32\end{array}$ & $\begin{array}{c}m g m . \\
\% \\
8.0\end{array}$ & $\begin{array}{l}\% \\
47\end{array}$ & $\begin{array}{c}g m . \\
\% \\
7.7\end{array}$ & $\begin{array}{c}g m . \\
\% \\
5.4 / 2.3\end{array}$ \\
\hline II & $\begin{array}{l}18-19 \\
19-20 \\
20-21 \\
21-22 \\
22-23 \\
23-24\end{array}$ & $\begin{array}{l}.5 \\
.5 \\
.5 \\
.5 \\
.5 \\
.5\end{array}$ & $\begin{array}{l}1.0 \\
1.0 \\
1.0 \\
1.0 \\
1.0 \\
1.0\end{array}$ & $\begin{array}{l}7 \\
7 \\
7 \\
7 \\
7 \\
7\end{array}$ & $\begin{array}{l}.2 \\
.2 \\
.2 \\
.2 \\
.2 \\
.2\end{array}$ & $\begin{array}{l}139 \\
139 \\
139 \\
139 \\
139 \\
139\end{array}$ & $\begin{array}{l}79 \\
79 \\
79 \\
79 \\
79 \\
79\end{array}$ & $\begin{aligned}- & 5.0 \\
- & 1.7 \\
+ & 0.6 \\
+ & 0.1 \\
+ & 2.3 \\
+ & 1.5\end{aligned}$ & $\begin{array}{r}+96 \\
+99 \\
+93 \\
+78 \\
+54 \\
0\end{array}$ & $\begin{array}{l}+12 \\
+15 \\
+29 \\
+28 \\
+35 \\
+23\end{array}$ & $\begin{array}{r}+54 \\
+53 \\
+60 \\
+49 \\
+37 \\
+5\end{array}$ & 136.7 & 4.0 & 95.4 & 23.3 & 11.1 & 4.0 & 31 & $\begin{array}{r}10.7 \\
\\
8.0 \\
6.7 \\
7.6\end{array}$ & 47 & 8.0 & $5.5 / 2.5$ \\
\hline III & $\begin{array}{r}24-25 \\
25-26 \\
26-27 \\
27-28\end{array}$ & $\begin{array}{l}.4 \\
.4 \\
.4 \\
.4\end{array}$ & $\begin{array}{l}2.0 \\
2.0 \\
2.0 \\
2.0\end{array}$ & $\begin{array}{l}7 \\
7 \\
7 \\
7\end{array}$ & $\begin{array}{l}1.0 \\
1.0 \\
1.0 \\
1.0\end{array}$ & $\begin{array}{l}308 \\
308 \\
308 \\
308\end{array}$ & $\begin{array}{l}136 \\
136 \\
136 \\
136\end{array}$ & $\begin{array}{l}-8.6 \\
=9.1 \\
=8.9 \\
-8.9\end{array}$ & $\begin{array}{l}-18 \\
-29 \\
-70 \\
-59\end{array}$ & $\begin{array}{r}+20 \\
0 \\
-18 \\
-23\end{array}$ & $\begin{array}{l}+7 \\
-22 \\
-63 \\
-40\end{array}$ & 137.5 & 4.0 & 101.0 & 27.9 & 11.1 & 3.7 & 25 & 6.1 & 46 & 7.1 & $4.9 / 2.2$ \\
\hline & 28 & & & & & & & & & & & 135.5 & 3.8 & 99.0 & 26.6 & 11.1 & 3.8 & 38 & 10.0 & 46 & 7.6 & $5.3 / 2.3$ \\
\hline
\end{tabular}

Patient J. M.

Period I. Fasting with water only.

Period II. 1200 calorie diet.

Period III. Fasting with salt mixture.

noying. He found no discomfort from taking the salt mixture, and believed it allayed his hunger somewhat. Acetonuria increased, and at the end of the period was found to be 3 plus. Five stools were passed during this period, in contrast to one stool during Period I.

\section{DISCUSSION}

Administration of the salt mixture in both cases was accompanied by an increase in the number of stools passed. B. S. had two stools in the four days of starvation with the salts, both of which were somewhat more liquid than usual for him; whereas no stools were passed in his other period of starvation and his colon was evacuated by tap water enema at the end of the period. J. M. passed five stools with the salt mixture, but only one during starvation without the salts. In both cases the amount of $\mathrm{K}, \mathrm{Na}$ and $\mathrm{Cl}$ recovered from the stools was but little affected by the salt mixture, indicating almost complete absorption of these elements. Nor was the stool content of nitrogen altered.

Both patients lost weight, nitrogen, and presumably some potassium, sodium and chloride during their foreperiods. B. S. lost 3.5 kilos in weight, J. M. lost 5 kilos; so that both began their total starvation periods in approximately equal status. In both cases also, the six-day feeding period failed to restore either the weight or the previously lost nitrogen, so that both patients began their second total starvation periods with less weight and less total nitrogen than was present at the beginning of the first starvation periods. It has been noted that undernourished and chronically debilitated persons can be maintained in nitrogen equilibrium on lower intake of both calories and nitrogen than normal, healthy, vigorous persons $(4,5)$. As a corollary, an individual would be expected to lose less nitrogen when subjected to a fast which began when he had already lost some nitrogen, than when subjected to a fast begun in full state of nutrition. Benedict's fasting man lost less nitrogen per day as the fasting progressed (1). Our patients lost less nitrogen in the second fasting period than in the first (patient B. S. lost $6 \mathrm{gm}$. less and patient J. M. lost $25 \mathrm{gm}$. less), though in both cases the weight losses in the two fasting periods were the same. Since the salt mixture was given to B. S. in his initial period of fasting and to J. M. in his second period of fasting, it may be concluded that the administration of the salt mixture did not exert any appreciable sparing effect on the nitrogen balance during starvation, nor did it appreciably alter the amount of weight lost.

Comparison of the potassium balance in the starvation periods, with and without ingestion of the salt mixtures, reveals that the results in the two 
patients were not identical. B. S., to whom the salt mixture was given in his first starvation period and water only in the second starvation period, sustained losses of potassium that were almost identical-150 meq. and 165 meq., respectively. This patient began each fasting period with approximately the same amount of potassium in his body, since, in the six-day interval when he was fed, there had been replacement of all but 9 meq. of the potassium lost in the initial fast. The greater loss of potassium was exhibited in the period during which less nitrogen was lost; so that one might conclude that the salt mixture had effected a small saving of potassium to the organism.

In the case of J. M., the salt mixture was given during the second period of starvation, and seemingly effected a marked sparing action on the amount of potassium lost. During Period I there was a deficit of 250 meq. $\mathrm{K}$; during Period III the loss was only 21 meq. This patient had not retained nitrogen during his six-day interval when fed, and had only partially repleted the potassium lost in the initial fast. Thus, in this patient, administration of the salt mixture was accompanied by a large saving of potassium during his fourday fasting period. Whether or not this sparing of body stores of potassium was beneficial to the patient cannot be stated; there was no detectable difference in his symptoms during the two fasting periods, and weight loss was practically identical. The full repletion of potassium during the feeding interval in B. S., far greater than the comparative repletion of nitrogen; and the repletion of 142 meq. of the previously lost 250 meq. of potassium by $J . M$. during the feeding interval, even in the face of negative nitrogen balance, furnish corroborative evidence of our previous observation that, after brief periods of starvation, potassium is repleted more rapidly than nitrogen (3).

Both patients lost large quantities of sodium and chloride in both starvation periods; the administration of the salt mixture appeared to influence the magnitude of these losses but little. In both patients, during the intervening period when they were on a 1200 calorie diet with average $\mathrm{Na}$ intake, there was retention of this element amounting to twice the losses sustained in the first starvation period. This over-repletion of these extracellular elements is in line with previous observations that, during total intravenous feeding before and after surgical operations, the amounts of sodium and chloride retained varies widely, depending on the general nutritional state and the status of hydration at the time (6). Both the patients in this study thus began their second period of starvation with more sodium and chloride in their bodies than was present at the beginning of the first starvation period. Both patients lost a little less of these elements when the salt mixture was given, and since one of the patients received the salts in his first fast while the other received them in the second, one may conclude that the administration of salts effected a slight reduction in the overall losses of sodium and chloride. However, when one compares the balance of sodium and chloride on the first day of starvation with and without the salt mixture, there is a striking difference, the losses in both instances having been almost negated by the salt administration. Except for Period I in which J.M. lost 205 meq. sodium and 212 meq. chloride (ratio $1: 1$ ), the movement of these two electrolytes was in general parallel, with approximate ratio of $3 \mathrm{Na}$ to $2 \mathrm{Cl}$, as in extracellular fluids. As previously mentioned, there was no appreciable difference in the weight losses sustained by either patient as the result of the administration of the salt mixture.

The overall movements of calcium and phosphorus are exceedingly difficult to interpret in balance studies of brief duration. When dietary calcium and phosphorus are abruptly changed from high intake to low and vice versa, there has been observed a highly variable "lag period" before the stool analyses reflect the altered diet (7). This is presumably due to the fact that all the calcium and phosphorus which will eventually reach the rectum may not traverse the gut at a uniform speed, certainly not coincident with the movement of carmine which is usually used to mark beginning and ending of metabolic periods. For these reasons no attempt will be made here to interpret balance data on these two substances. However, the urinary content of phosphorus during the starvation periods seemed to be affected little or none by the administration of the salt mixture to either patient. The urine of B. S. contained more phosphorus when he ingested the mixture than 
when he did not; on the other hand, the reverse was true in the case of J. M. It seems more likely that little or none of the phosphorus of the mixture was absorbed (since there was considerable excess of calcium), and that the urinary phosphorus was a reflection of its movement with nitrogen; for the urinary phosphorus was greater in both patients in their first starvation period when nitrogen losses were greater.

There was no appreciable effect of the salt mixture on the urinary excretion of calcium in the case of J. M., but B. S., who received the greater amount of calcium in the salt mixture, exhibited a heightened calciuria of $150 \mathrm{mgm}$. per day when given the salt mixture, which was interpreted as an indication that some of the calcium had been absorbed.

Concentration in the serum of the various ions under consideration followed, in the main, the expected pattern. There was no appreciable change in non-protein nitrogen during the starvation periods. Serum bicarbonate fell slightly in all four fasting periods. Concentration of potassium rose very slightly except in the second starvation period of J. M. (in which he received the salt mixture). The concentrations of sodium and chloride fell slightly in all four fasting periods, seemingly uninfluenced by the administration of the salt mixture. The serum concentration of calcium remained stable in J. M., but rose $2 \mathrm{mgm}$. per 100 cc. in B. S. during starvation when he was given the salt mixture. This was reflected in a considerable increase in calciuria coincidently. The rise in serum calcium in this period is all the more striking when compared with its behavior during B. S.'s second fast, during which there was a fall in serum calcium. The conclusion seems inescapable that there was appreciable absorption of calcium from the salt mixture.

Fasting blood sugar concentration fell $40 \mathrm{mgm}$. per $100 \mathrm{cc}$. in each of the starvation periods of $\mathrm{B}$. $\mathrm{S}$., the mild diabetic. Uric acid (8) rose in the serum of both patients to high levels during the fasting periods, as previously noted in undernutrition regimes in normal persons (3).

\section{SUM MARY}

Two obese male patients were subjected to two periods each of four days' starvation. During one fast each patient received only water; in the other a salt mixture, containing approximately the amounts of sodium, chloride, potassium and phosphorus of a 1200 calorie diet, was given in addition to the water. Between the two fasting periods both patients were fed for six days a diet containing 1200 calories.

Administration of the salt mixture resulted in no lessening of the nitrogen lost by fasting and effected no alteration in the amount of weight lost. In one patient there appeared to be considerable saving of potassium from the salt mixture, in the other patient none.

On the first day of the fasts, large savings of sodium and chloride were manifest from the salt mixtures, but thereafter excretion of these elements was rapid; and the total amounts of sodium and chloride lost over the four days were the same in the fasting periods with and without the salt mixtures.

The sodium, chloride and potassium of the mixtures were almost completely absorbed, as judged from the quantities of these elements in the stools and by the increased amounts appearing in the urine. There was no appreciable rise in phosphaturia when the salt mixture was given, as compared with fasting alone. In one of the patients there was heightened calciuria and hypercalcemia as a result of the salt mixture.

The concentrations in the serum of sodium, chloride and potassium were uninfluenced by the salt administration.

Stools were more frequent during fasting when the salt mixture was given, but only minimal amounts of the administered salts were recovered in the stools.

\section{BIBLIOGRAPHY}

1. Benedict, F. G., A study of prolonged fasting. Carnegie Institute of Washington, 1915, Publication No. 203.

2. Gamble, J. L., Ross, G. S., and Tisdall, F. F., The metabolism of fixed base during fasting. J. Biol. Chem., 1923, 57, 633.

3. Howard, J. E., Bigham, R. S., Eisenberg, H., Wagner, D., and Bailey, E., Studies on convalescence. IV. Nitrogen and mineral balances during starvation and graduated feeding in healthy young males at bed rest. Bull. Johns Hopkins Hosp., 1946, 78, 282.

4. Howard, J. E., Protein metabolism during convalescence after trauma. Arch. Surg., 1945, 50, 166. 
5. Browne, J. S. L., Schenker, V., and Stevenson, J. A F., Some metabolic aspects of damage and convalescence. J. Clin. Invest., 1944, 23, 932.

6. Mason, R. E., and Howard, J. E., to be published. Preliminary report in: Minutes of the Conference on Metabolic Aspects of Convalescence. New York, Josiah Macy, Jr., Foundation, 13th meeting, June 10-11, 1946, p. 143.
7. Reifenstein, E. C., Jr., Albright, F., and Wells, S. L., The accumulation, interpretation, and presentation of data pertaining to metabolic balances, notably those of calcium, phosphorus, and nitrogen. J. Clin. Endocrinol., 1945, 5, 367.

8. Folin, O., Standardized methods for determination of uric acid in unlaked blood and in urine. J. Biol. Chem., 1933, 101, 111. 